\title{
COASTAL MOSLEM'S CREATIVE ECONOMY DEVELOPMENT MODEL : CASE STUDY IN KENJERAN SURABAYA
}

\author{
Tika Widiastuti \\ Department of Sharia Economics, Faculty of Economics and Business \\ Universitas Airlangga \\ Email: tika.widiastuti@feb.unair.ac.id \\ Sunan Fanani \\ Department of Sharia Economics, Faculty of Economics and Business \\ Universitas Airlangga \\ Email: sunanfananis@yahoo.com \\ Imron Mawardi \\ Department of Sharia Economics, Faculty of Economics and Business \\ Universitas Airlangga \\ Email: imron.mawardi@feb.unair.ac.id
}

\begin{abstract}
ARTICLE HISTORY
Received:

30 November 2017

Accepted:

20 December 2017

Online available:

25 February 2018

Keywords:

Coastal Communities,

\section{ABSTRACT}

The aim of this study is to understand how coastal moslem's creative economy development are. This study has used qualitative approach with study case strategy. Data collection has done by interviewing the informants i.e. Head of Kelurahan Sukolilo and Creative Industry's stakeholder nearby Kenjeran, Surabaya. The result of this study is an appropriate model to develop coastal moslem's socio-economics is a holistic-integrated developments. The model involved sort of stakeholders viz. fishermans, seafood crackers producers, the government, NGO's, and universities.
\end{abstract}

Creative Economy,

Kenjeran, Sosio-

Economic

Development

Kata Kunci :

Masyarakat Pesisir,

Ekonomi Kreatif,

Kenjeran,

Pengembangan Sosio-

Ekonomi

\section{ABSTRAK}

Tujuan dari penelitian ini adalah untuk mengetahui bagaimana perkembangan ekonomi kreatif masyarakat muslim pesisir. Penelitian ini menggunakan pendekatan kualitatif dengan strategi studi kasus. Pengumpulan data dilakukan dengan mewawancarai informan yaitu Kepala Kelurahan Sukolilo dan pemangku kepentingan Industri Kreatif di dekat Kenjeran, Surabaya. Hasil penelitian ini merupakan model yang tepat untuk mengembangkan sosio-ekonomi masyarakat pesisir merupakan perkembangan terpadu holistik. Model tersebut melibatkan 
pemangku kepentingan. nelayan, produsen kerupuk ikan, pemerintah, LSM, dan universitas.

\section{INTRODUCTION}

East Java Province has a vast area with $46,428 \mathrm{~km} 2$, divided into 29 districts and 9 cities, 662 sub districts also 8506 villages. Total population approximately 40.903 .400 people has shaped in 11.925.192 head of families with gender compositions are $49,72 \%$ male and 50,28\% female and it make East Java become the second largest populations in Indonesia.. Furthermore, it made a chance for social problems to grow rapidly throughout East Java developments process. According to East Java Central Bureau of Statistic representative, in 2013, The East Java's Gini index attained 0,36, that figured that inequality in East Java is higher enough.

High inequality in East Java has caused by high poverty level. One of contributor to this level is the people who lives in coastal areas. Coastal People's Poverty especially fisherman as a consequence by fishermans' seasonal dependency character.. The dependency has caused by their inabilities accessing technologies, capitals, and has not exist yet to another jobs in coastal areas as well as has experienced by price injustice, finited resources and has not a strong foundation in their organizations as of has delicate position than anothers (Satria,2012).

Fisheries and Marine sector in East Java has a huge potention. It showed by the result of not only in captured fisheries but also in aquaculture that has reached 1.390.995 tonne (BPS,2015). It should become an economic resources that will achieve high contribution so must be well-managed in order to sustainable resources for people.

One of ploy that can make East Java's fisheries and marines become passably through creative economy. Creative economy is value-added creations by idea basic that shaped from creative human resources and science based, include heritage and technology to create new things (RAJM Ekonomi Kreatif 2015-2019). East Java has a substansial potention in creative economy.

Creative economy consists of fifteen sectors i.e. 1) Advertising, 2) Architechture, 3) Finest Art, 4) Crafts, 5) Design, 6) Fashion, 7) Films, Videos, and Photography, 8) Interactives game, 9) Music, 10) Performing Art, 11) Publishing and Printing, 12) Computers and Softwares, 13) Television and Radio, 14) Research and Developments, 15) Culinary East Java has an enormous potention in creative economy. Based on Central Bureau of Statistics in 2013, according to constant price, East Java Province has three sub sector from the fifteen that has a big roles to RGDP viz. culinary sectors has $12,23 \%$ or equal with 145,86 Trillion, Crafts sector has $1,91 \%$ equal with 22,73 Trillion, and 
Publishing and Printing Sectors has 1,55\% equal with 18,54 Trillion. If this sector will develop so it can has a impact to East Java's RGDP.

Kenjeran is one of the most iconic place and recently become the most family alternative-recreational place in East Surabaya. Beside that, demographically in Kenjeran, there are villages that Islam as majority religion, and full dependent with sea production. Besides working as a fisherman, they also cultivate a marine products becomes snack crackers such as crackers sea eggplant, cucumbers, skin snapper, stingray skin to the stomach of fish. snack crackers in fact are part of the culinary industry sub sectors of the creative economy of East Java which has great potential.

Production and marketing of marine products crackers in Kenjeran has form of small home-based business but has been spread in almost all Sukolilo districts, Kenjeran. Recently, there is no direct relationship of cooperation between the regions cluster (which occur naturally) and community / group seafood crackers processing in Kenjeran. That requires a model of creative economic development in order to manage potential resources and marine services in Kenjeran and adapted to the socio-cultural community Kenjeran The majority are Moslems, in order to be accepted by society, ensuring sustainability and in accordance with the local cultural identity of Moslem society so as to provide the maximum benefit for the welfare of the Moslem community in Kenjeran.

In the framework of the economic empowerment that in fact Kenjeran coastal communities and Moslem majority it needs a productive empowerment solution, this certainly can not be achieved easily and in a short time. Thus, the community empowerment program in Kenjeran by Surabaya city government through various forms of assistances both venture capital assistance, infrastructure and other forms has prudent to reach the goals, appropriate and of interest, so as to empower Kenjeran residents which is the coastal communities and the Moslems as majority through the culinary sub sectors industry of the creative economy. Therefore, it is important to be studied in a comprehensive model of creative economic development of Moslem communities in Kenjeran coastal areas.

The purpose of this research is to create a creative economic model development of Moslem communities in Kenjeran coastal.

\section{LITERATURE REVIEW}

\section{Coastal's People and Poverty}

Coastal community is a group of people or groups together occupy a territory which has had a distinctive culture associated with the dependence of coastal resource (Satria, 2009). The main characteristics of coastal communities is highly dependent on the season. In the fishing season they are very busy to go to sea, famine forced the majority of them are unemployed because fishing activity was declining. The condition that 
makes their economies very vulnerable, especially in the lean season. In that season they were forced to make loans to the collector (Boss) to meet daily needs. This causes many of those who sell their catch to a collector at a very low price.

In general, women of coastal communities to manage fish and other marine products on a small scale for sale individually or as laborers for companies managing the fish, while the majority of children's activities help to go to sea. So many of them do not attend school or drop out of school (Nugroho and Rokhim, 2012). This is in line with research Andriati (1992) in Kusnadi (2000), which revealed that one of the strategies adopted by fishermen households in overcoming economic difficulties is to encourage their wives to participate earning an income to meet their daily needs.

Conditions of vulnerable coastal communities are economically result in identical conditions with poor coastal communities. Reviewing aspects of poverty in the region provide a comprehensive framework for poverty reduction efforts. Poverty is a condition of absolute or relative where a person or group of people in a region for natural reasons, cultural, or structural, cause they do not have the capacity to meet their basic needs according to the procedure specified values or norms that apply in the society. By social aspects and politics, poverty indicates a growth of community aspirations and limited perception and artificial, prioritizing decisions in the short term and the lack of independence of the community (Nugroho and Rokhim, 2012).

\section{Management Concept}

According to article 5 in Law No. 7 of 2007, Coastal Areas and Small Islands management includes planning, utilization, monitoring, and control of human interaction in the use of Coastal Power Sources and Small Islands as well as natural processes on an ongoing basis in an effort improve the welfare of society and maintain the integrity of the Republic of Indonesia.

Management according to Big Indonesian Dictionary (KBBI), means the process, ways, actions to manage; the process of performing certain activities by moving the power of others; process that helps formulate a policy and objectives of the organization; or a process that provides oversight to all things involved in policy implementation and achievement of goals.

According to Yusran management model (2015) in general can load the appropriate part of the model include:

a. Comprehensive Management Model, is used to analyze changes in facilities and infrastructure management system as a whole. Besides, it serves as a benchmark in elaborating plans more specific goals towards broader

b. Setting Target models are required in order to implement a projection or estimate of the level of development for a certain period of time, through the analysis of demographic and population projections and projecting perfoment school and employment needs 
c. Model Costing and Cost effectiveness, it is necessary to analyze the management plan infrastructure is included into the economic criteria.

Coastal resource management by communities as an alternative solution as shown to provide a number of benefits for their livelihood guarantee, equal access to resources and conflict resolution mechanisms, is oriented towards sustainability.

\section{Resource Management Concepts In Islamic view}

In the view of Islam, forests, water, and energy and mineral resources are public property. Hence, its management should not be left to the private sector (corporatebased management) but must be managed entirely by the state (state-based management), and the results should be returned to the people in various forms. In a hadith, the Prophet SAW said:

"The Moslems has association in three things: water, pasture and fire (Abu Dawud, Ahmad, Ibn Majah: Imam Ash Sayukani, Nayl al Authar p. 1140)"

As for the management and utilization of natural resources by individual sector are possible but are not to be monopolized, meaning the natural resources utilized together and and not greedy. Management of the state on natural resources have resulted in two advantages; First, the results of management become a source of income for the state budget large enough to meet the various needs of the country; and secondly, the country could break away from dependence on foreign debt.

\section{Economic Empowerment In Islamic Perspective}

The concept of empowerment in community development discourse is always associated with the concept of independence, participation, networking and empowerment keadilan. Essentially laid on the strength of the individual and social levels. Related assumptions used in order to realize empowerment in the context of the Islamic Society Development, Mudzakir (1986: 12-15) mentions the following assumptions:

1) At the core of community empowerment efforts can be seen as laying a social order in which human beings fairly and openly can do business as a manifestation of the capabilities and potentials that need (material and spiritual) can be met. Community empowerment, therefore, intangible bid a business project to the public, but an improvement of social structures that promote justice. Community empowerment is basically to plan and prepare a meaningful social change for the improvement of the quality of human life.

2) The community empowerment is not seen as a process of administration of the party that has something to those who do not have. Framework of this understanding will plunge to businesses that merely gives momentary pleasure and are patchy. For example, the provision of financial assistance fresh (fresh money) to the community will only result in the loss of independence in the community or 
creating dependency. As a result of the worse is the mental growth of "ask". In fact, in Islam, asking it levels several degrees lower than on giving.

3) Empowerment of people should be seen as a learning process to the people so that they can independently make efforts improved quality of life. There is a process that is often overlooked that the development is social learning. Therefore, the real community empowerment is a collective process in which family life, neighborhood, and the state does not just prepare adjustments to the social changes that they go through, but actively directing such changes on unmet needs together.

4) The community empowerment, impossible without full engagement by the community itself. Participation is not simply defined as the presence of them to attend an event, but rather understood as their contribution in every step that must be passed by a program of community empowerment, especially in the stages of formulation of needs that must be met. The assumption was that the public that best know the needs and the problems they face

5) Community empowerment is a community development effort. Not probably feels the demand for community involvement in the development of a program when the public itself has no power or giving them enough to develop the economy. Therefore, there should be a system and mechanisms to empower communities. The community must be a belief that without their full involvement, improvement of the quality of their lives will not bring meaningful results. Often people empowerment begins with changing the way people view from the first note of "nrimo ing pandum" become active participatory economic devenlopment.

In Surah Al Hashr verse 7 is also explained the necessity of justice, by distributing wealth to the needy,

"What are the spoils (fai-i) that God has given to His Messenger (of the property) from the people of the townships, is for God, for the Apostle, kinsfolk, orphans, those poor and people who are on the way, so that it may not circulate between the rich among you. What is given unto the Apostle, then accept. And what he forbids you, then leave. And fear Allah. Verily Allah is severe in punishment. "(QS. Al-Hasr verse 7)

The text makes clear that the treasure exists in this world should not be circulated in one of the course. The capable commanded to care and utilize their wealth to help the needy so that they can earn a decent living too. The concept of empowerment in verse and QS. Al Hashr clear that God commands us to always strive to empower needy Moslems. 


\section{Creative Economy Concept}

Creative economy is closely related to the creative industries, but the creative economy has a broader scope of creative industries. Creative economy is not only related to the creation of economic value added, but also the creation of added value in the social, cultural and environmental. Therefore, the creative economy in addition to improving the competitiveness, it can also improve the quality of life of the Nations. Creative industry part or subsystem of the creative economy, where creative industries drive the creation of economic value in the era of the creative economy. In the process of value creation creative, creative industries not only create economic transactions, but also social and cultural transactions. In general, the creative industries are defined as industries which produce output from the utilization of creativity, expertise, and individual talents to create value-added, employment, and improved quality of life.

Based on the master plan for development of the creative economy until 2025, the direction of creative economic development from 2015 to 2019 is the consolidation of creative economic development by emphasizing the achievement of competitiveness on the basis of competitiveness of natural resources, culture, and human resources quality and creative in using science and technology, as well as institutional strengthening to create a business climate conducive to the development of local creative industries.

\section{RESEARCH METHOD}

\section{Research Approach}

This research is a descriptive qualitative research. Based on the explanations that have been described in the background of the issues to refer to the formulation of the problem, as well as the purpose of the study, the researchers used a descriptive research model that aims to make in-depth study and a systematic description, factual and accurate information on the relationship between the phenomenon or phenomenon. The method used in this study is the case study method. According to Yin (2003: 18) "an empirical study which investigated the phenomenon in the context of real life, where the boundaries between the phenomenon of the context does not seem firmly and multi resources used".

\section{Types and Data Resources}

The data used in this study are primary data and secondary data. Primary data is empirical data obtained or collected by researchers directly from respondents or informants by using questionnaires and interviews making it easier for researchers to analyze the problem. In this case, the source (informants) are as follows: 1) responsible for the development activities of coastal communities in the Department of Fisheries 
and Marine Resources of East Java Province, the Head of Marine, Coastal, and Supervision and Head of Marine, Coastal and Small Islands, 2) 3 of the groups that received economic empowerment program in coastal areas.

In this study, secondary data can be obtained through a publication in the form of journals, newsletters, magazines and reports the activities of the Department of Fisheries and Marine Resources of East Java Province. All data have been processed will be analyzed with descriptive analysis approach.

\section{Data Collection Procedures}

In qualitative research, the data collection process moves from empirical field in an attempt to build a theory of data. This data collection process includes the steps as follows:

a. In-depth interviews (Indepth Interview)

Interviews were conducted both openly and structurized and questions focused on the problem, so that the information collected is quite exhaustive. Openness that led to the allowances to be able to ferret out information honesty and objectivity of the information to provide what is actually gained.

b. When in the study site (getting a long)

In this stage researchers to mingle with the situation where the studied and did a personal relationship to maintain familiarity with the informant, investigators follow all applicable provisions of the study sites, then trying to make observations, either directly or indirectly, discussion, exchange of information, resulting in discourse at the level of ethics, namely in terms of the views of researchers with information from informants emik.

c. Collect Data (logging the data)

Collect data (logging the data)

At this stage the researchers used data collection techniques include:

1) Indepth Interview

Interviews were conducted both openly and structurized and questions focused on the problem, so that the information collected is quite exhaustive. Openness that led to the allowances to be able to ferret out information honesty and objectivity of the information to provide what is actually gained.

2) Observation

This observation techniques either directly or indirectly, or formally or informally used to examine the economic activities of Moslem communities in coastal areas. This is done in order to complete the data in the field of primary and secondary data collected previously, as well as secondary data.

3) Dokumentation

This technique is done to obtain secondary data requirements, decisions of archives and documents relevant to the needs of researchers retrieved data. 


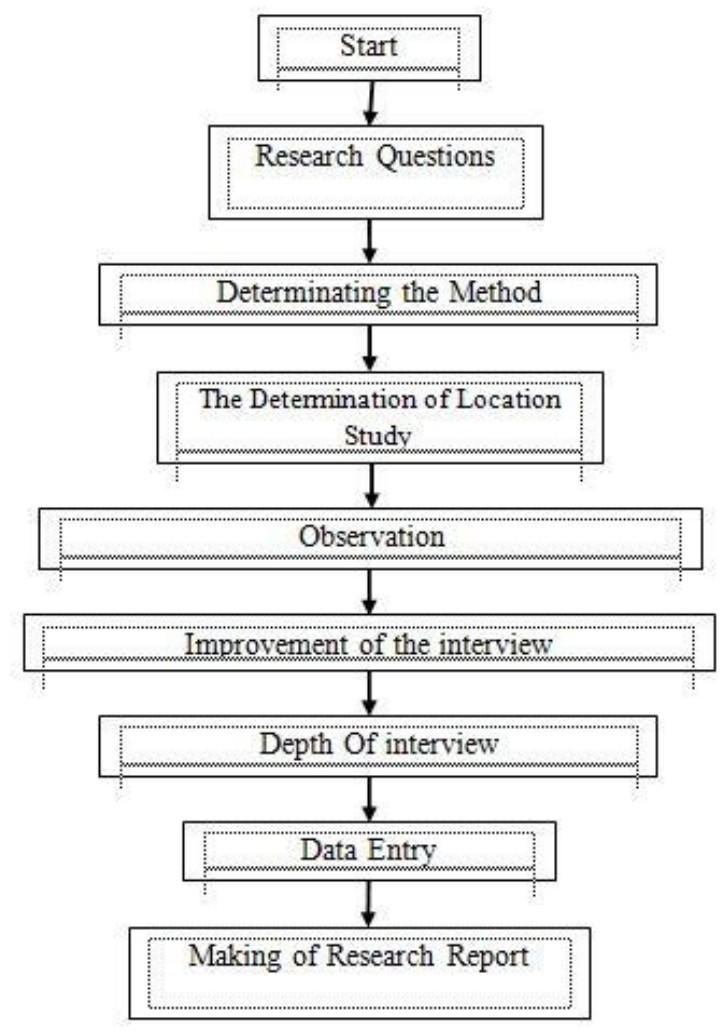

Resource: Author, 2016

Picture 1.

Flowchart Research

\section{RESULT AND DISCUSSIONS}

\section{Overview of Seafood Crackers Processing Industry in Kenjeran's Costal.}

Surabaya is one of the metropolitan cities in Indonesia which has an area of approximately $326.81 \mathrm{~km} 2$. One sub district in Surabaya is Sukolilo which has a location within walking distance of Kenjeran, the only marine tourism locations in Surabaya. One District of Bulak village has an area of $6,72 \mathrm{~km} 2$ with a population of 5584 inhabitants. Based on BPS data in 2013, the Village Kenjeran including one of the villages with very low economic level in Surabaya Surabaya East.

In general, social and economic characteristics of coastal residents Kenjeran Surabaya summarized in Table 1 
Table 1

Socioeconomic Characteristics Population Coastal Kenjeran Surabaya

\begin{tabular}{|c|c|c|}
\hline No & Aspect & Overview \\
\hline 1 & $\begin{array}{l}\text { The Resident's } \\
\text { Characteristics }\end{array}$ & $\begin{array}{l}\text { 1) Fisherman Coast Community } \\
\text { 2) Javanese and Maduranese } \\
\text { 3) There are seven exists groups of fisherman }\end{array}$ \\
\hline 2 & $\begin{array}{l}\text { Resident } \\
\text { Population }\end{array}$ & $\begin{array}{l}\text { 1) At the end } 2012 \text { around } 5500 \text { inhabitants } \\
\text { 2) Densely achieve } 64 \text { inhabitants/ha } \\
\text { 3) Sex Ratio between } 98-100\end{array}$ \\
\hline 3 & Education level & $\begin{array}{l}\text { 1) Resident Average age }>30 \text { years old : elementary } \\
\text { school-junior high school graduated } \\
\text { 2) Resident Average age }<30 \text { years old : elementary } \\
\text { school Graduated }\end{array}$ \\
\hline 4 & Productivity & $\begin{array}{l}\text { 1) Amount of age resident around } 70 \% \\
\text { 2) Majority entrepreneur, fisherman, dan employee } \\
\text { 3) Resident have capability within management of } \\
\text { marine product, shells craft, and fish fumigation }\end{array}$ \\
\hline
\end{tabular}

Resource: Author Data Proccess

Sukolilo urban village became the center of production centers processed seafood crackers in Surabaya. This is because most of the village residents Sukolilo addition to having the main livelihood as fishermen, they also develop seafood processing business crackers, crackers Industry marine products in the household based mostly Kenjeran both small and large scale. Small scale industry consists of a family of fishermen who process the catch of the sea became crackers in their homes each

\section{Results Description}

\section{First Informant}

The first informant was headman New Sukolilo. The first informant chosen for the executive headman as directly related to the economic empowerment of the Moslem community in Kenjeran creative. The first informant explained that the training has been widely held in the village Sukolilo like packinging, training on food coloring, given the various processing training fatherly made from fish such as fish balls, fish nuggets and fish cakes. the city government also provided assistance to the fishing vessel. other than that the city government provide Fish Bulak Centre for selling. Universities in Surabaya also provide training to the community such as a widya mandala university invited citizens to come to eventnya fatherly training and selling at their event.

The main project of the city government of Surabaya Alone This is for structuring the fishing village. Structuring the fishing village were budgeted at 13 billion. Various steps have been done Surabaya Government for structuring the village fishermen such as wheelbarrows waste disposal has been replaced with bins of 105 pieces, wooden walkways for access to the fishing village, the construction of the road was given a box culvert for drainage that are not easily flooded and left the impression of shabby, The 
arrangement also makes the fishing village of Surabaya city government to build a bridge whose budget reached 200.9 billion. It is also equipped with a dancing fountain are colorful.

The criteria for the arrangement of this fishing village is the village that looks rundown. While the village is not visible villages are not given such arrangement. obstacles faced when fishing village management that is less conscious to environmental hygiene and Human Resources Low.

\section{Second Informant}

The second informant is one of the SMEs in the region Kenjeran who got some empowerment program, named Mrs. Ervina. She is a Moslem aged 40 years and is local of the area Kenjeran. Mrs. Ervina ever get creative economic development program of the city government, which is a mentoring program of Disperindagin (Department of Trade and Industry).

In terms of financing, Mrs. Ervina get a loan from BTPN Sharia. The initial loan of Rp 2,000,000 per person, which was accepted by 15 people, and 15 people were gathered into one group funding. Once the fund is managed, annually can be increased up to two times and it has been running for four years. As collateral all group members must attend the meeting, held two weeks.

The products produced by SMEs Mrs. Ervina itself includes four types of crackers, namely: kupang crackers, crackers lujuk, crackers squid, and crab crackers, with a wide variety of models and colors.

\section{Third Informant}

The third informant is a seafood processing businessman. She called Mrs. Tilawati. She was 38 years old and she is Moslem. She received training from the department of cooperatives as much as two times. The training she ever follow is training pengenai food coloring. In addition, she received training from ajinomoto about MSG which not using borax. In addition to receiving training Mrs. Tilawati get helped by selling tool for operational assistance. Third informant obtain financing from BTPN sharia. He received capital funding of 10 million. BTPN sharia does not use the collateral only use joint responsibility. Where Mrs. tilawati formed a group of as many as 15 members.

Improvement of the city government of Surabaya affects sales levels. Due to the condition of Mrs. Tilawati store increasingly clean and there is parking for visitors to her shop. The assistance provided by BTPN Sharia and the government affects her sales. She can increase her production capacity because it can buy a wide range of tools for production 


\section{Fourth Informant}

The four informants are entrepreneurs who processed fish products. Her name is lis Widayati. He was 36 years old Moslem Since childhood she has lived in the territory of the sukolilo sub district. Mrs. lis Widayati received training from the local government for business development of result of the sea in 2011. Received training from the department of cooperatives. In addition to getting the training he received financial aid from the government of Surabaya as many as 500 thousand rupiah and get helped by in the form of an operational tool seller.

In addition to getting help from the local government of 500 thousand rupiah Informant 4 getting capital financing from BTPN Sharia. He received capital funding of 10 million. BTPN Sharia does not use the collateral only use joint responsibility that does not incriminate Her.

\section{Fifth Informnat}

Fifth informant is Mr. Bayu Erlangga. He is is the companion of SMEs seafood processed. He was 28 years old.

Assistance which he did by holding empowerment by organizing village meetings. Meeting held in the village is related to the development of entrepreneurship education. After a meeting of the village known after the problems they are given assistance in the form of a coaching clinic to provide direction in terms of what they already know. The problem that has been resolved expected ampu raise their turnover in order to meet their own needs. The criteria to be developed comes from Bappeko. So that the determination of who should be fostered from Bappeko. The final goal of the program is empowering them prosperous and able to meet their basic needs.

The obstacles faced by SMEs when assistance that is the mentality of the seafood processing is low. The effect is much like training they expect something else from that training when it is only there so that the training conducted training runs less than the maximum.

\section{Holistic Model Moslem Community Economic Development Coastal Creative Economy SMEs based in the East Coast Surabaya}

Based on the analysis of field research and general guidance exercising program PEMP Ministry of Maritime Affairs and Fisheries, the one right model, to socio-economic development of coastal Moslem community is to use a holistic development paradigm, namely development undertaken comprehensive and integrated manner. This model involving multiple parties namely fishermen, seafood cracker manufacturers, governments, NGOs and universities. In detail the flow of a holistic development model implementation Minapolitan crackers processing of marine products in the Coastal Kenjeran depicted in the chart below: 


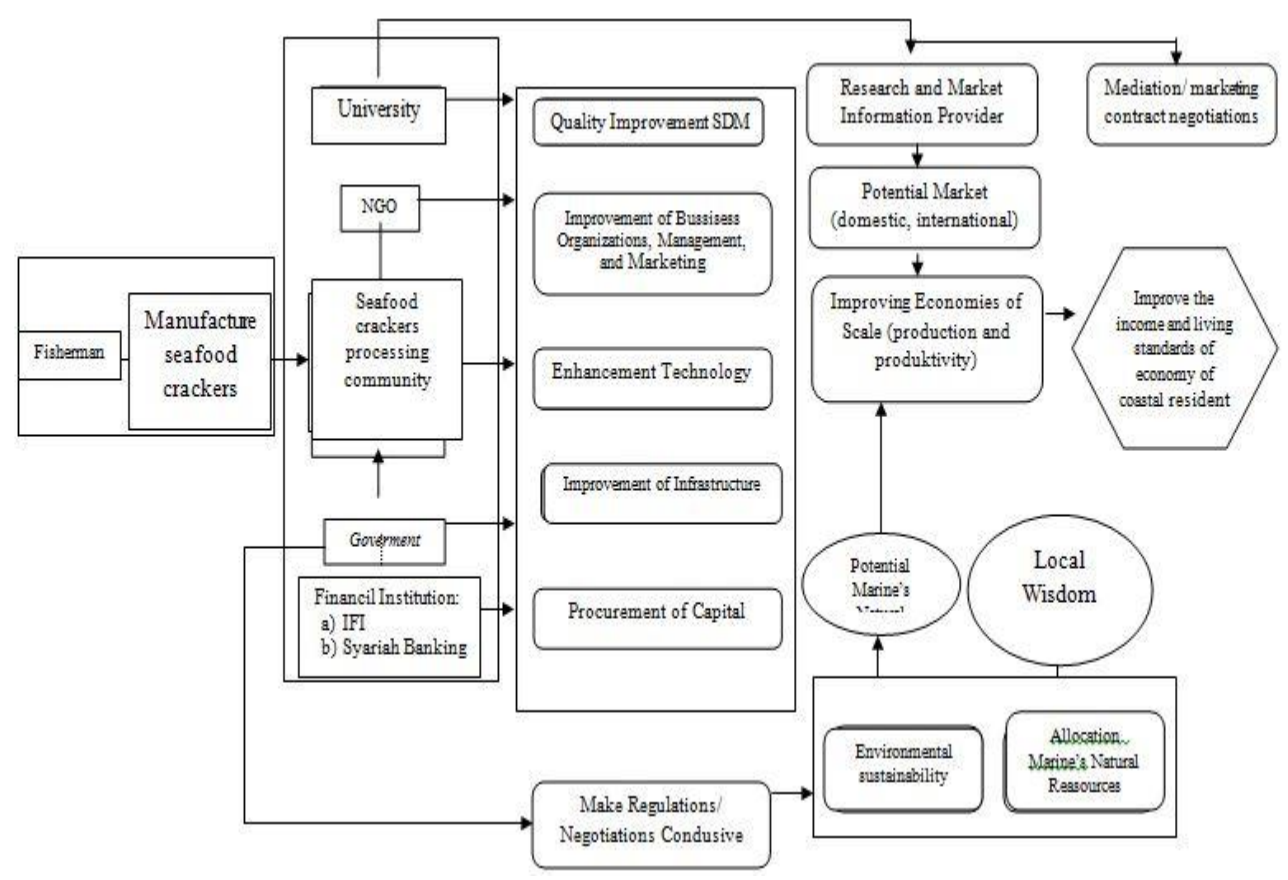

Resource: Author Data Processed

Picture 2

Holistic Model Moslem Community Economic Development Coastal Creative Economy based in the East Coast Surabaya

Fishermen is a major supplier of raw materials for the production of processed seafood crackers managed by the producers of seafood crackers. In this model the cracker manufacturer of marine products into objects of empowerment; while the Government, Non Government Organization (NGO), universities, financial institutions (both IFI and Sharia banks in this case the Islamic banking) to work together to assist the development of industrial zones minapolitan processing the seafood crackers. To facilitate communication, coordination and partnerships between businesses cracker manufacturer of marine products with the parties, the community formed crackers seafood businesses that are based on existing community..

Cooperation between the four parties (Government, Non Government Organization (NGO), universities, lembagakeuangan) premises businesses community is expected to realize improvements include:

1. Improving the quality of human resources. This is particularly important given the education level remains low Kenjeran coastal communities which constitute the majority of elementary school and junior high. With the improvement of the quality of human resources is expected to entrepreneurs may increase the scale of production and product quality to the optimum. 
2. Improvement of business organization, management and marketing. During this cracker seafood processing industry that is based household and still fragmentary. Likewise, the fisherman as the supplier of raw materials, they do everything individually. This has become one of the main factors of business organization, management and marketing of marine products processing industry crackers have not organized systematically, so the results are still not optimally. Therefore, with the establishment of a community based on household businesses, then together with the four sides above can improve and maximize the business organization, management and marketing.

3. Improved technology. Since many years ago businesses looking for raw materials and process them in a way that inherited generations of their ancestors. Everything is still completely conventional, so the productivity is low and product quality still does not meet national standards. Therefore, it is necessary to enhance which technology to realize efficient processing.

4. Improved infrastructure. Sentra crackers seafood processing industry is located in areas that are relatively rundown, although adjacent to Kenjeran Beach travel but also the tourist infrastructure is still inadequate. Public facilities such as roads to the tourist attractions are still in the process of improvement and public transportation is very difficult to access. It is one of the factors that make people less interested in visiting these places, so that domestic buyers crackers seafood is also relatively small. With the improvement of the infrastructure is expected to attract tourists, both domestic and international to visit the tourist, who later also expected to increase demand for cracker products marine products.

5. Procurement of Capital. During this time the majority of businesses use private funds which are limited to doing business crackers marine products, and a few others do partnerships with banks, especially Bank Sharia. However, in general, the available funds are very limited and insufficient production, so that the amount of production is still on a small scale. Even if there are capital, management is still an individual basis and usually only used to increase the capital purchase of raw materials. With their fourth collaboration between communities and relevant stakeholders, the capital should be managed for overall business development.

\section{CONCLUSIONS}

Based on the research results and discussion, conclusions can be drawn as follows: Holistic Model Area Development Minapolitan Crackers Marine Product Processing is a model development undertaken comprehensive and integrated manner. This model involving multiple parties namely fishermen, seafood cracker manufacturers, governments, NGOs and universities. By involving various parties, it is expected Minapolitan crackers seafood processing industry in Kenjeran can be developed as much as possible. As the development of processing industry in Kenjeran seafood cracker, it 
will encourage the development of other economic sectors Goal of this model is the increased income and standard of living of coastal Moslems, so that the welfare of the Moslem coastal communities can be achieved.

The proposed recommendation after doing this research are as follows:

1. Development and improvement of infrastructure in the Coastal Kenjeran city officials need to be improved given the potential for fisheries and marine owned.

2. Policies to improve the quality of human resources in the Coastal Kenjeran through formal education and training is needed by the government of Surabaya, look at the condition of the labor force an average education is primary school / equivalent.

3. Coordination and cooperation between government and local communities in the Coastal Kenjeran needs to be done with a family approach to ensure that policies will be taken is the result of joint consultation so that implementation was received support from many parties.

\section{REFERENCES}

Apridar, M. K. (2011). Ekonomi Kelautan dan Pesisir. Yogyakarta: Graha Ilmu.

Badan Pusat Statistik Surabaya Tahun 2013. www.surabayakota.bps.go.id. Diakses pada tanggal 13 Agustus 2016 Pukul 08;30

Badan Pusat Statistik Provinsi Jawa Timur. (2013). Produksi Ikan Menurut Kabupaten/Kota dan Sub Sektor Perikanan (Ton) www.jatim.bps.go.id diakses pada tanggal 11 Agustus 2016. Pukul 21.22

Badan Pusat Statistik Provinsi Jawa Timur. (2015). Gini Ratio Menurut Kabupaten/Kota Tahun 2008 - 2014.www.jatim.bps.go.id diakses pada tanggal 11 Agustus 2016. Pukul 22.00

Darmawan, Yusran, dkk. (2015). Membangun Indonesia dari Pinggiran; Kisah-Kisah Pendampingan Masyarakat di Pesisir.Jakarta: Kementerian Kelautan dan Perikanan (KKP) dan Destructive Fishing Watch (DFW-Indonesia).

http://nasional.tempo.co/read/news/2016/01/07/173733906/soekarwo-santai-

tanggapi-4-kabupaten-jawa-timur-daerah-tertinggal, dilihat 21 Januari 2015, Jam 10.30

http://www.slideshare.net/hidonis/12-model-pengelolaan-kekayaan-alam-dalam-islam, dilihat 21 Januari 2015, Jam 12.50. 
Kementerian Kelautan dan Perikanan. (2013). Profil Kelautan Dan Perikanan Provinsi Jawa Timur Untuk Mendukung Industrialisasi KP.Jakarta: Kementerian Kelautan dan Perikanan (KKP).

Kementerian Kelautan dan Perikanan (2014). Analisis Data Pokok Kelautan dan Perikanan 2014.Jakarta: Kementerian Kelautan dan Perikanan (KKP).

Kementerian Kelautan dan Perikanan (2014). Kelautan dan Perikanan dalam Angka Tahun 2014. Jakarta, Kementerian Kelautan dan Perikanan (KKP).

Kementrian Pariwisata dan Ekonomi Kreatif (2014). Ekonomi Kreatif : Kekuatan Baru Indonesia menuju 2025, Rencana Aksi Jangka Menengah 2015-2019, Jilid 1. Jakarta: Kementrian Pariwisata dan Ekonomi Kreatif.

Madiong, Baso. (2012).Pokok-Pokok Pikiran Pengelolaan Sumber Daya Alam Dalam Perpektif Hukum Islam Dan Hukum Positif, artikel (online) https://basomadiong.wordpress.com/2012/07/25/39/, dilihat 21 Januari 2015, Jam 12.48.

Marfiani, Teni. (2004). Evaluasi Program Pemberdayaan Masyarakat Pesisir (Studi Kasus di Kecamatan Parigi Kabupaten CiamisProvinsi Jawa Barat) Skripsi. Bogor: Institut Pertanian Bogor

Purwanti, P. (2010). Model Ekonomi Rumah Tangga Nelayan Skala Kecil. Malang: UB Press.

Sara, L. (2014). Pengelolaan Wilayah Pesisir (Gagasan Memelihara ASet Wilayah Pesisirdan Solusi Pembangunan Bangsa). Bandung: Penerbit Alfabeta.

Satria, A. (2009). Pesisir dan Laut untuk Rakyat. Bogor: IPB Press. . (2015). Pengantar Sosiologi Masyarakat Pesisir. Jakarta: Yayasan Pustaka Obor Indonesia.

Suparmoko, M. (2013). Ekonomi Sumber Daya Alam dan Lingkungan (Suatu Pendekatan Teoritis), Edisi Keempat Revisi. Yogyakarta: FEB UGM.

Suyanto, B. (2004). Strategi Pengentasan Kemiskinan Struktural pada Masyarakat Nelayan Tradisional Jawa Timur. Badan Penelitian dan Pengembangan Jawa Timur bekerjasama dengan Lembaga Penelitian Universitas Airlangga. 
Widiastuti,Fanani, Mawardi |Jurnal Ekonomi dan Bisnis Islam, Vol. 3, No. 2, Juli-Des 2017

Yin, Robert K. (2003). Appliations of Case Study Research: Second Edition. New Delhi: Sage Publications India Pvt. Ltd 